J. Clin. Chem. Clin. Biochem.

Vol. 17, 1979, pp. 647-651

\title{
Comparative Evaluation of Different Spectrophotometric Methods for the Determination of Small Amounts of Carboxyhaemoglobin ${ }^{1}$ ), ${ }^{2}$ )
}

\author{
By G. Heinemann, Karin Löschenkohl and H. Schievelbein \\ Institut für Klinische Chemie (Vorstand: Prof. Dr. H. Schievelbein), Deutsches Herzzentrum München
}

(Received March 7/May 18, 1979)

Summary: Four spectrophotometric methods measuring $\mathrm{HbCO}$ were investigated in comparison with an analyzer (CO. Oximeter) in order to find a method determining $\mathrm{HbCO}$ fractions ${ }^{2}$ ) below 0.10 with sufficient reliability. The COOximeter was chosen as "reference" method because results of other authors with this instrument yielded good agreement with other methods, e.g. IR-spectrometry, GLC, van Slyke. Only the five wavelength method of Commins \& Lawther ((1965) Brit. J. Industr. Med. 22, 139-143) can be recommended, for it yielded CV's and sensitivities comparable to the CO-Oximeter. The within-run precision had CVs of $2.3 \%$ to $4.7 \%$, the sensitivity was 0.0021 to 0.0028. The method is suited even for $\mathrm{HbCO}$ measurements of shorter series.

\section{Vergleichende spektrophotometrische Bestimmung geringer HbCO-Anteile}

Vier manuelle spektrophotometrische Methoden zur Bestimmung von $\mathrm{HbCO}$ wurden im Vergleich zu einem teilmechanisierten Gerät (CO-Oximeter) geprüft, ob mit ihnen Anteile unter 0,10 am Gesamt-Hb $\mathrm{HbCO}$ zuverlässig gemessen werden können. Wir wählten das CO-Oximeter als "Referenz"-Methode, da die Meßwerte anderer Autoren mit diesem Gerät sehr gute Ubereinstimmung mit der IR-Spektrometrie, der GC und der Methode von van Slyke zeigten. Von vier geprüften Methoden kann lediglich die 5-Wellenlängen-Methode von Commins \& Lawther ((1965) Brit. J. Industr. Med. 22, 139-143) empfohlen werden, die an Zuverlässigkeit dem CO-Oximeter nicht nachsteht. Die Präzision in der Serie hatte einen VK von 2,3-4,7\%, die Empfindlichkeit lag bei 0,0021-0,0028. Die Methode eignet sich auch gut für HbCO-Bestimmungen in kleineren Serienlängen.

\section{Introduction}

Several methods exist for the quantitative spectrophotometric determination of carboxyhaemoglobin ( $\mathrm{HbCO}$ ) in human blood, which are supposed to be simple and quick. In general these methods are sufficient for the measurement of rather high levels of $\mathrm{HbCO}$, e.g. in cases of CO-intoxication. The reason is that a slight deviation of the measured value near the lethal ḦbCO fraction is not important with regard to the clinical diagnosis. On the other hand, no details are known about the reliability of some spectrophotometric methods for low contents of HibCOO.

In the course of our investigations of the chronic toxicity of small amounts of $\mathrm{HbCO}$ with regard to the etiology of vascular diseases, the need arose to compare the different

\footnotetext{
1) Presented in part at the Tenth International Congress on Clinical Chemistry, February, 1978, Mexico City, Mexico.

2) Throughout this paper SI Units are used, thus " $2 \%$ " $\mathrm{HbCO}$ is now expressed as the fraction of total haemoglobin, i,e. 0.02 .
}

methods frequently used. We therefore measured $\mathrm{HbCO}$ fractions in blood below 0.10 . We chose three different $\mathrm{HbCO}$ fractions in the range of 0.02 to 0.06 and evaluated some values of quality control like within-run precision, accuracy, sensitivity, and efficiency. The CO-Oximeter was chosen as "reference" method because results of other authors with this instrument yielded good agreement with other methods, e.g. IR-spectrometry, GLC.

\section{Materials and Methods}

\section{Equipment}

Spectrophotometer, model 25, Beckman Instruments, USA. CO-Oximeter IL 182, and Tonometer IL 237, Instrumentation Laboratory, USA.

Microliter syringe $701 \mathrm{~N}$, Deutsche Hamilton GmbH, FRG. Blood mixer, Coulter Electronics, GB.

Conway diffusion units

Microliter cups, Eppendorf Gerätebau, FRG. 


\section{Chemicals}

Merck, Darmstadt: Palladium chloride $\left(\mathrm{PdCl}_{2}\right)$, Hydrochloric acid $1 \mathrm{~mol} / \mathrm{l}$, Sodium carbonate $\left(\mathrm{Na}_{2} \mathrm{CO}_{3}\right)$, Ammonia solution $14.6 \mathrm{~mol} / \mathrm{l}$

Sigma Chemie, München: Chlorpromazine hydrochloride, Saponin Linde AG, München: Carbon monoxide, Oxygen.

Preparation of $\mathrm{HbCO}-c o n t a i n i n g$ blood samples

Fresh heparinized blood was obtained by venipuncture of a female non smoker and then divided into two samples. One sample was oxygenated by tonometry with humidified pure oxygen, the other one was subjected to tonometry with pure carbon monoxide. Mixtures with various $\mathrm{HbCO}$ contents were prepared by mixing different volumes of the two saturated samples as described by Amenta (1). The final $\mathrm{HbCO}$ fractions of about $0.02,0.04$, and $0.06 \mathrm{HbCO}$ were adjusted using the CO-Oximeter and if necessary either $\mathrm{O}_{2}$ - or $\mathrm{CO}$-saturated blood was added to the primarily mixed samples until the $\mathrm{HbCO}$ fractions had the above mentioned values. However, it should be born in mind that it is difficult to obtain nominal values by mixing parts of $\mathrm{O}_{2}$ - and CO-saturated blood, because $\mathrm{HbO}_{2}$ is

\section{Principles of the four spectrophotometric methods}

In the palladium chloride method of Lee et al. (3), $\mathrm{CO}$ is released from blood by the addition of sulfuric acid, then absorbed by the $\mathrm{PdCl}_{2}$ solution. The resulting free palladium (Pd) forms a coloured complex with chlorpromazine hydrochloride, which can be measured at $565 \mathrm{~nm}$. The three other spectrophotometric methods are based on the specific absorption of the different $\mathrm{Hb}$ derivatives and are performed by diluting the sample with a $\mathrm{Na}_{2} \mathrm{CO}_{3}$ /Saponin solution (Two wavelength method (4)) or with a weak solution of ammonia, respectively (Three wavelength (1), and Five wavelength method (2)). The principles are illustrated in Figures 1 to 4.

$\mathrm{CO}+\mathrm{PdCl}_{2}+\mathrm{H}_{2} \mathrm{O} \rightarrow \mathrm{CO}_{2}+2 \mathrm{HCl}+\mathrm{Pd}$

$\mathrm{Pd}+$ chlorpromazine hydrochloride $\longrightarrow$ violet coloured complex

Photometric determination at $565 \mathrm{~nm}$

Calculation

$\frac{B-T_{1}}{B-T_{2}} \times \frac{0.1}{V}=\mathrm{HbCO}$

$\mathrm{B}=$ absorption of reagent blank

$\mathrm{T}_{1}=$ absorption of blood sample

$\mathrm{T}_{2}=$ absorption of $\mathrm{CO}$ saturated blood

$\mathrm{V}=$ sample volume

Fig. 1. The principle of the palladium chloride method (3): Microdiffusion technique with reduction of palladium chloride.

Blood $+\mathrm{Na}_{2} \mathrm{CO}_{3} /$ Saponin solution

Photometric determination at 546 and $578 \mathrm{~nm}$

Calculation

$Q=\frac{A_{546}}{A_{578}}$

$\mathrm{HbCO}$ is estimated by $\mathrm{Q}$ and a standard curve

Fig. 2. The principle of the two wavelength method (4): Blood is diluted with $\mathrm{Na}_{2} \mathrm{CO}_{3}$ solution $(9.4 \mathrm{~mol} / \mathrm{l})$ with the addition of $1.5 \mathrm{~g}$ Saponin.

3) Note: In the description of the $\mathrm{PdCl}_{2}$ method by Lee et al. (3) there is a misprint on page $658: 88.66 \mathrm{mg} \mathrm{PdCl}$ is correct instead of $886.6 \mathrm{mg}$.
Blood + ammonia solution

Photometric determination at 498,560 , and $575 \mathrm{~nm}$

Calculation

$R=\frac{A_{575}-A_{560}}{A_{498}}$

$\mathrm{R}_{1}: \mathrm{O}_{2}$ saturated blood

$\mathrm{R}_{2}$ : CO saturated blood

$\mathbf{R}_{\mathbf{x}}$ : blood sample

$\frac{\mathbf{R}_{1}-\mathbf{R}_{\mathbf{x}}}{\mathbf{R}_{\mathbf{1}}-\mathbf{R}_{\mathbf{2}}}=\mathrm{HbCO}$

Fig. 3. The principle of the three wavelength method (1): Blood is diluted with ammonia solution $(7.8 \mathrm{mmol} / \mathrm{l})$.

Blood + ammonia solution

Photometric determination at $414,420,426,559$ and $575 \mathrm{~nm}$

\section{Calibration}

Blood + ammonia solution

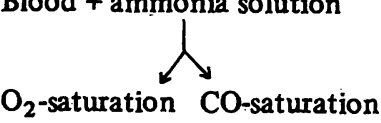

$A_{575}-A_{559}=d_{0}$

$A_{420}-\left(A_{414}-A_{426}\right): 2=h_{0}$

Blood sample

Same measurements, but without CO-saturation. Determination of $d$ and $h$.

Calculätion

$\frac{\mathrm{h} \times \mathrm{d}_{0}}{\mathrm{~h}_{0} \times \mathrm{d}}=\mathrm{HbCO}$

Fig. 4. The principle of the five wavelength method (2): Blood is diluted with ammonia solution $(23,5 \mathrm{mmol} / 1)$.

\section{Results and Discussion}

The evaluation of the four spectrophotometric $\mathrm{HbCO}$ methods was necessarily restricted to measurements of the within-run precision and their comparison with the CO-Oximeter. The measurement of the day-to day precision could not be performed on account of the short stability of the samples, because we found the $\mathrm{HbCO}$ fraction of blood enclosed in microliter cups and stored at room temperature to be constant for only three days, and only 3.5 to 4 days when stored at $4{ }^{\circ} \mathrm{C}$. Thereafter, the $\mathrm{HbCO}$ fraction decreased. Our findings conformed to those of Commins \& Lawther (2). Transport of $\mathrm{HbCO}$ blood samples is only possible within the mentioned time intervals.

As can be derived from the literature $(5,6,7)$, the COOximeter yielded $\mathrm{HbCO}$ values, which showed good agreement with the values obtained by other well established methods, such as the method of van Slyke, infrared spectrophotometry (IR), and gas liquid chromatography (GLC). The regression lines of these comparisons pass close to the points and their equations and co- 
efficients of correlation are as follows: van Slyke/CO. Oximeter: $\mathrm{y}=-0.0692+0.9884 \mathrm{x}, \mathrm{r}=0.994 ; \mathrm{IR} / \mathrm{CO}$. Oximeter: $y=3.1021+0.9782 x, r=0.998 ;$ GLC/CO. Oximeter: $y=-1.0039+1.045 x, r=0.998$. We therefore used the CO-Oximeter as a "reference" method for the four spectrophotometric methods. But on the other side, it should be mentioned that in an interlaboratory survey on $\mathrm{HbCO}$, which took place in the European Community in 1977, it was found that the CO-Oximeter yielded slightly increased values, if the fraction of $\mathrm{HbCO}$ was below 0.03 (14).

\section{Precision}

The results of the measured within-run precision of the methods used and the CO-Oximeter are presented in table 1 . The repeated measurements of the within-run precision with the 2 wavelength and 3 wavelength method often yielded worse coefficients of variation, as shown in table 1 , whereas the $\mathrm{CV}$ s of the $\mathrm{PdCl}_{2}$ method remained nearly unchanged. The lowest $\mathrm{CVs}$ of within-run precision were obtained by the method of Commins \& Lawther (2) and by the CO-Oximeter respectively. The sensitivity was 0.0021 to 0.0028 obtained by us with the former method.

Tab. 2. Comparison of the 4 spectrophotometric methods with the CO-Oximeter.

$A$ and $B$ represent different blood samples

\begin{tabular}{|c|c|c|c|c|}
\hline \multirow{2}{*}{$\begin{array}{l}\text { Methods } \\
\text { A }\end{array}$} & \multirow[t]{2}{*}{$\mathbf{N}$} & \multicolumn{3}{|c|}{$\begin{array}{l}\text { Means of the } \mathrm{HbCO} \text { fraction meas - } \\
\text { urements }\end{array}$} \\
\hline & & & & \\
\hline $\begin{array}{l}\text { CO-Oxi- } \\
\text { meter }\end{array}$ & 9 & 0.031 & 0.051 & 0.069 \\
\hline $\mathrm{PdCl}_{2}$ & 9 & 0.027 & 0.048 & 0.064 \\
\hline \multicolumn{5}{|l|}{ B } \\
\hline $\begin{array}{l}\text { CO-Oxi- } \\
\text { meter } \\
2 \text { wave- } \\
\text { length }\end{array}$ & $\begin{array}{r}9 \\
10\end{array}$ & $\begin{array}{l}0.022 \\
0.023\end{array}$ & $\begin{array}{l}0.041 \\
0.045\end{array}$ & $\begin{array}{l}0.060 \\
0.068\end{array}$ \\
\hline $\begin{array}{l}3 \text { wave- } \\
\text { length }\end{array}$ & 10 & 0.025 & 0.042 & 0.061 \\
\hline $\begin{array}{l}5 \text { wàve- } \\
\text { length }\end{array}$ & 12 & 0.022 & 0.041 & 0.059 \\
\hline
\end{tabular}

Comparison of the spectrophotometric methods with the CO-Oximeter

The results in table 2 represent the means of 9 to 12 determinations. The mean values of the $\mathrm{PdCl}_{2}$ method in relation to the $\mathrm{CO}=0 x$ ximeter are somewhat lower and show a nearly constant difference. The reason may be a loss of carbon monoxide during the reaction. Good agreement was found by comparing the mean values of the CO-Oximeter and the 5 wavelength method. Although the mean values of the CO-Oximeter show only small deviations from the 2 wavelength and 3 wavelength method the variations of the two latter methods are much bigger and deviate sometimes considerably from the values of the IL 182. Figures 5 to 8 show the scatter diagrams and regression lines of the methodological comparisons.

Tab. 1. Description of the 3 different $\mathrm{HbCO}$ concentration fractions measured with the CO-Oximeter and the four spectrophotometric methods.

\begin{tabular}{|c|c|c|c|c|}
\hline \multirow{2}{*}{$\begin{array}{l}\text { Method } \\
\mathrm{PdCl}_{2}\end{array}$} & \multirow[b]{2}{*}{$\begin{array}{l}\mathrm{n} \\
\mathrm{x} \\
\mathrm{s} \\
\mathrm{CV}(\%) \\
\mathrm{x}_{\max } \\
\mathrm{x}_{\min }\end{array}$} & \multicolumn{3}{|c|}{$\begin{array}{l}\text { Description of the } 3 \text { different } \mathrm{HbCO} \\
\text { fractions }\end{array}$} \\
\hline & & $\begin{array}{l}9 \\
0.0212 \\
0.00491 \\
23.2 \\
0.0267 \\
0.0150\end{array}$ & $\begin{array}{l}9 \\
0.0427 \\
0.00543 \\
12.7 \\
0.0515 \\
0.0342\end{array}$ & $\begin{array}{l}9 \\
0.0637 \\
0.00650 \\
10.2 \\
0.0731 \\
0.0568\end{array}$ \\
\hline $\begin{array}{l}2 \text { wave- } \\
\text { length }\end{array}$ & $\begin{array}{l}\mathrm{n} \\
\overline{\mathrm{x}} \\
\mathrm{s} \\
\mathrm{CV}(\%) \\
\mathrm{x}_{\max } \\
\mathrm{x}_{\min }\end{array}$ & $\begin{array}{l}10 \\
0.0234 \\
0.00789 \\
33.7 \\
0.0340 \\
0.0120\end{array}$ & $\begin{array}{c}10 \\
0.0456 \\
0.00758 \\
16.6 \\
0.0520 \\
0.0360\end{array}$ & $\begin{array}{l}10 \\
0.0684 \\
0.00478 \\
7.00 \\
0.0760 \\
0.0600\end{array}$ \\
\hline $\begin{array}{l}3 \text { wave- } \\
\text { length }\end{array}$ & $\begin{array}{l}\frac{n}{x} \\
s \\
C V(\%) \\
x_{\max } \\
x_{\min }\end{array}$ & $\begin{array}{l}10 \\
0.0253 \\
0.01003 \\
39.5 \\
0.0456 \\
0.0170\end{array}$ & $\begin{array}{l}10 \\
0.0427 \\
0.01116 \\
26.1 \\
0.0570 \\
0.0302\end{array}$ & $\begin{array}{c}10 \\
0.0613 \\
0.01042 \\
19.9 \\
0.0770 \\
0.0481\end{array}$ \\
\hline $\begin{array}{l}5 \text { wave- } \\
\text { length }\end{array}$ & $\begin{array}{l}\frac{\mathrm{n}}{\mathrm{x}} \\
\mathrm{s} \\
\mathrm{CV}(\%) \\
\mathrm{x}_{\max } \\
\mathrm{x}_{\min }\end{array}$ & $\begin{array}{l}12 \\
0.0220 \\
0.00105 \\
4.76 \\
0.0243 \\
0.0216\end{array}$ & $\begin{array}{l}12 \\
0.411 \\
0.00122 \\
2.96 \\
0.0432 \\
0.0405\end{array}$ & $\begin{array}{l}12 \\
0.0596 \\
0.00139 \\
2.33 \\
0.0614 \\
0.0571\end{array}$ \\
\hline $\begin{array}{l}\text { CO-Oxi- } \\
\text { meter }\end{array}$ & $\begin{array}{l}\mathbf{n} \\
\bar{x} \\
\mathbf{s} \\
C V(\%) \\
x_{\max } \\
x_{\min }\end{array}$ & $\begin{array}{l}9 \\
0.0221 \\
0.00096 \\
4.34 \\
0.0240 \\
0.0210\end{array}$ & $\begin{array}{l}9 \\
0.0416 \\
0.00152 \\
3.64 \\
0.0440 \\
0.0390\end{array}$ & $\begin{array}{l}9 \\
0.0605 \\
0.00196 \\
3.24 \\
0.0647 \\
0.0587\end{array}$ \\
\hline
\end{tabular}

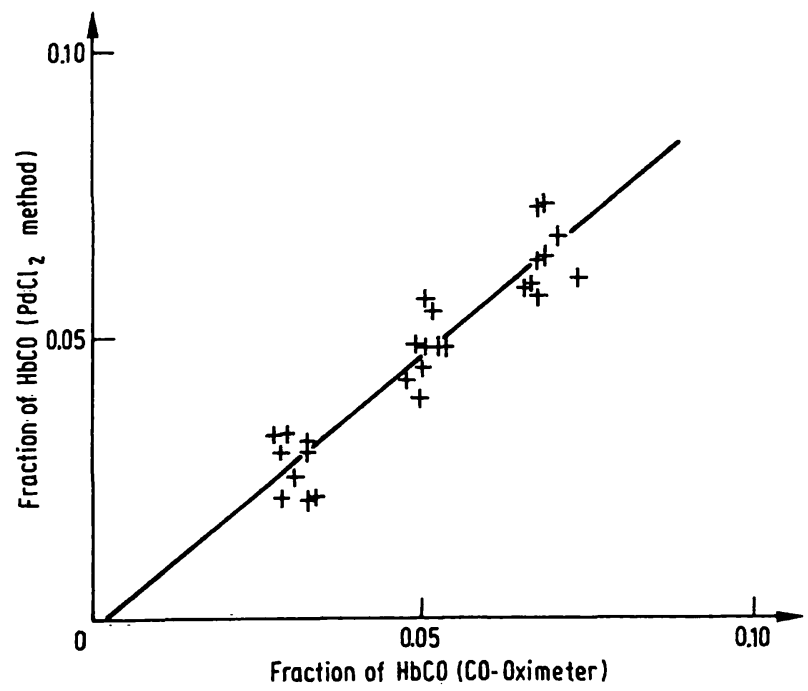

Fig. 5. Comparison of the $\mathrm{HbCO}$ fraction found with the $\mathrm{PdCl}_{2}$ method and the CO-Oximeter. Regression analysis: $y=-0.1876+0.9540 x, r=0.938, s_{y x}=0.782$. 


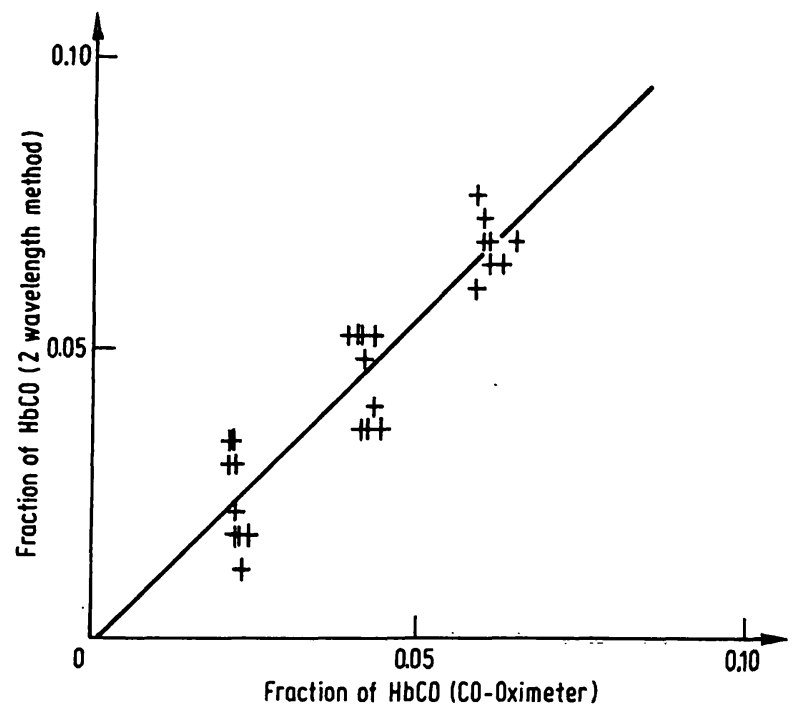

Fig. 6. Comparison of the $\mathrm{HbCO}$ fraction found with the 2 wavelength method and the CO-Oximeter. Regression analysis: $y=-0.0671+1.1169 x, r=0.845, s_{y x}=0.782$

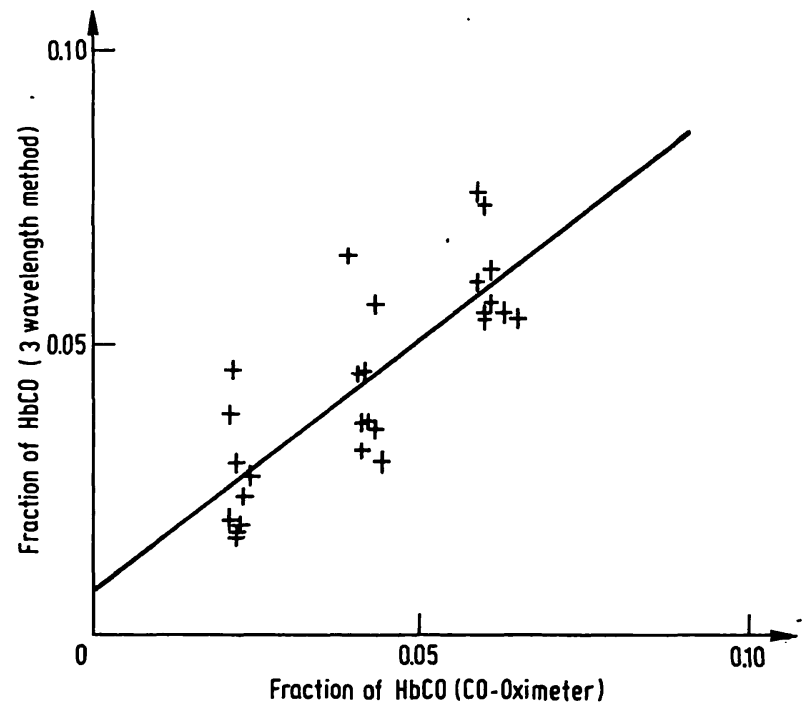

Fig. 7. Comparison of the $\mathrm{HbCO}$ fraction found with the 3 wavelength method and the CO-Oximeter. Regression analysis: $y=0.7368+0.8718 x, r=0.803, s_{y x}=1.059$.

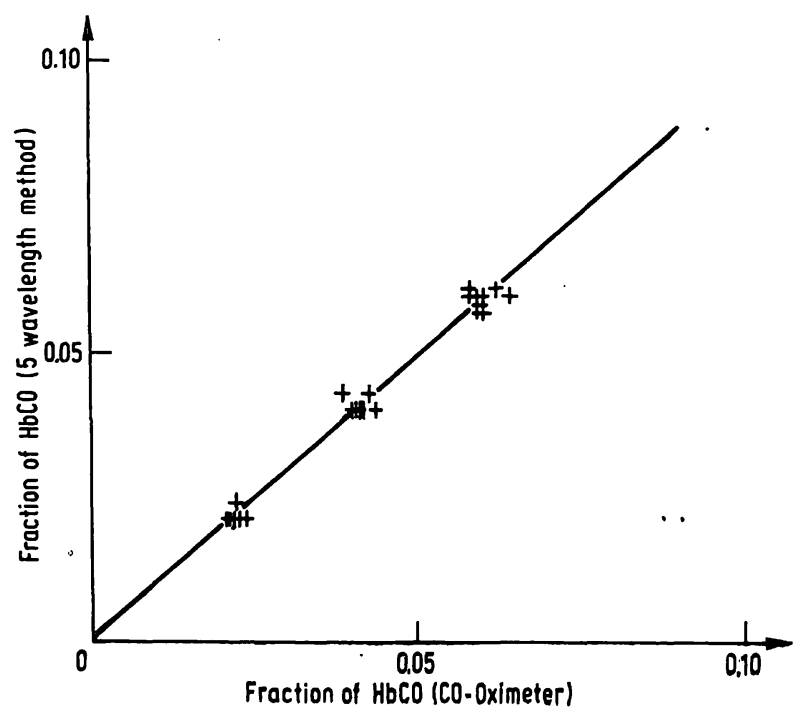

Fig. 8. Comparison of the $\mathrm{HbCO}$ fraction found with the 5 wavelength method and the CO-Oximeter. Regression analysis: $\mathrm{y}=0.0731+0.9698 \mathrm{x}, \mathrm{r}=0.986, \mathrm{~s}_{\mathrm{yx}}=0.186$

\section{Statistical calculations}

Using the nonparametric rank test of Wilcoxon, Mann \& Whitney (8), it was of interest to see whether the four spectrophotometric methods are able to differentiate between the $\mathrm{HbCO}$ fractions of $0.02 / 0.04$ and $0.04 / 0.06$ respectively. The 3 wavelength method differed on the level of probability of $\alpha=0.5 \%$, the other methods on the level of $\alpha=0.1 \%$. This statistical statement, based merely on differences of the medians, is evidently limited with respect to its practical meaning, if one considers the variations and sensitivities of the methods. With the 2 wavelength, 3 wavelength or $\mathrm{PdCl}_{2}$ method several measurements have to be made to obtain a more relevant mean value, especially in cases of $\mathrm{HbCO}$ intoxication more reliable values are desired. As mentioned earlier, if a $\mathrm{HbCO}$ intoxication is suspected, it is generally sufficient to know whether $\mathrm{HbCO}$ is elevated.

Differences of $0.01 \mathrm{HbCO}$ or less are nōt measurable using the 2 wavelength, 3 wavelength, and $\mathrm{PdCl}_{2}$ method. But these requirements are, to a large extent, fulfilled by the 5 wavelength method and the CO-Oximeter. Both methods have comparable sensitivities and coefficients of variation. Incidentally the easy handling and the quick calculation of the CO-Oximeter should be mentioned. The 5 wavelength method requires some more expenditure of time ( $20 \mathrm{~min}$ for one sample, including $15 \mathrm{~min}$ of $\mathrm{O}_{2}$ saturation) and work than the $\mathrm{CO}-\mathrm{Oxi}$ meter, but nevertheless it is suited for short series. For rapid measurements of longer series the CO-Oximeter is more efficient. From our experience we can support the findings of Lily et al. (9) and Astrup (10). Buchet et al. (11) compared the method of Commins \& Lawther with the microdiffusion technique of Vignoli et al. (12) and the infrared technique of Boudène et al. (13) and found excellent correlations. However, they favour the Commins \& Lawther's technique too, because it had several advantages over the other two techniques.

We calculated $\mathrm{d}_{\text {crit. }}$ for our spectrophotometer to be $\mathrm{A}=\mathbf{0 . 0 3 5}$ according to a blood volume of $7 \mu \mathrm{l}$. Commins \& Lawther (2) suggested the calculation of the so-called $\mathrm{d}_{0}$ - and $\mathrm{h}_{0}$-value be performed orly once by establishing the method in a laboratory using different blood samples. We sometimes found distinct deviations in the blood of different volunteers. The best results were found if $d_{0}$ and $h_{0}$ are determined additionally in each sample. But this procedure makes it necessary to store a gas cylinder with carbon monoxide in the laboratory. Blood can be anticoagulated by oxalate, citrate or heparin. Of all of the investigated spectrophotometric methods, we can recommend preferably the method of Commins \& Lawther (2). 


\section{References}

1. Amenta, J. S. (1963), Standard Methods of Clinical Chemistry, Academic Press, Vol. 4, p. 31-38.

2. Commins, B. T. \& Lawther, P. J. (1965), Brit. J. Industr. Med. 22, 139-143.

3. Lee, K. T., Kit, O. A. \& Jacob, E. (1975), Microchim. Acta II, 657-663.

4. Richterich, R. (1971), Klinische Chemie, 3. Aufl. Verlag S. Karger, Basel, 393-394.

5. Malenfant, A. L., Gambino, S. R., Waraksa, A. J. \& Roe, E. I. (1968), 20 th National Meeting, American Ass. Clin. Chem., Washington, D. C.

6. Dubowski, K. M. \& Unke, J. L. (1973), Ann. Clin. Lab. Sci. 3, 53-65.

7. Maas, A. H. J., Hamelink, M. L. \& de Leeuw, R. J. M. (1970), Clin. Chim. Acta 29, 303-309.
8. Wilcoxon, F., Mann, H. B. \& Whitney, D. R., in: Sachs, L. (ed.) (1973), Angewand te Statistik, Springer Verlag Berlin, 230-238.

9. Lily, R. E. C., Cole, P. V. \& Hawkins, L. H. (1972), Brit. J. Industr. Med. 29, 454-457.

10. Astrup, P. (1977), Diskussionsbemerkung, 1. wissenschaft Symposium des Forschungsrates Rauchen und Gesundheit, Hamburg

11. Buchet, J. P., Lauwerys, R. R. \& Roels, H. (1974), Int. Arch. Arbeitsmed. 33, 269-275.

12. Vignoli, L., Cristau, B., Defretin, J. P. \& Viquoli, R. (1960), Arch. Mal. Prof. 21, 432-438.

13. Boudène, C., Godin, J. \& Roussel, A. (1973), Arch. Mal. Prof. 34, 449-456.

14. Commission of the European Communities Directorate General-Employment and Social Affairs (1977) Doc. V/F! $1315 / 77 \mathrm{e}$
Dr. G. Heinemann

Institut fü Klinische Chemie Deutsches Herzzentrum München Lothstr. 11 8000 München 2 
